\title{
Kontektualisasi Shurā dalam Demokrasi
}

(Studi Terhadap Pandangan dan Praktik Demokrasi Kiai dan Santri di Madura)

\section{Zainuddin Syarif}

IAIN Madura

\author{
Jamiah.duba@gmail.com
}

\begin{abstract}
Abstrak
Kontektualisasi syura dalam demokrasi dapat dilihat dari kegiatan ekstra kurikuler santri dalam pemilihan Ketua OSIS di lembaga pendidikan dibawa naungan pondok pesantren di Madura. Secara umum, santri telah mengenal dan mengimplementasikan sistem demokrasi dan menggunakan halnya dalam memilih pemimpin di lembaga pendidikan. Pesta demorasi ini telah mendidik santri untuk menerima dan mengikuti segala program yang direncanakan oleh pemenang kontestan pada pesta demokrasi di lembaga pendidikan yang dilaksanakan setiap tahun. Kaintannya dengan hal tersebut, santri telah melaksanakan syarat-syarat untuk menjadi pemimpin dimana salah satunya adalah melalui proses pemilihan dengan adanya perwakilan dari masih kelas dan juran yang telah tunjutk untuk mencalonkan diri sebagai kontestan. Disinilah proses ahl al hal wal al aqd diimplentasikan dalam kehidapan santri di pesantren untuk menentukan pemimpin dalam organisasi.
\end{abstract}

\section{Key Word: Shura, Demokrasi, dan Kontektuasasi}

The contextualization of shura in democracy can be seen from the extra-curricular activities of the students in the election of the Student Council Chair in educational institutions under the auspices of Islamic boarding schools in Madura. In general, students have recognized and implemented a democratic system and used this in electing leaders in educational institutions. This demonstration party has educated students to accept and participate in all programs planned by the winning contestants at the democratic party at educational institutions which are held every year. The kaintan with this is that the students have carried out the requirements to become leaders, one of which is through the selection process with representatives from still classes and juran who have shown themselves to run as contestants. This is where the process of ahl al hal wal al aqd is implemented in the life of students in Islamic boarding schools to determine the leader in the organization. 


\section{Pendahuluan}

Secara konsep penulis tidak menafikan bahwa Shurā dan demokrasi berada dalam bentangan yang berbeda. Tentu saja banyak penulis yang menyatakan bahwa shura dan demokrasi berbeda baik secara konsep maupun praktik. Begitu juga banyak tulisan yang menyatakan bahwa shura dan demokrasi secara subtansial mempunyai tujuan yang sama. Beberapa tulisan sebagai kajian terdahulu yang memperkuat pernyataan tersebut, diantaranya adalah; tulisan Bambang Arif Rahman ," Debating shura and democracy among British Muslim organizations," 1 . Dalam penelitian Rahman menyebutkan bahwa ada tiga tipologi kelompok besar di Inggris yang dapat memberikan pengaruh kepada masyarakat Islam dalam memberikan pandangan dan sikap terhadap shura dan demokrasi. Hizbut Tahrir bersikukuh dalam pandangannya bahwa Shurā sebagai acuan dalam memberikan pandangan dan sikap dalam menentukan kebijakan dan politik. Berbeda dengan kelompok Jama'ah tabligh, ${ }^{2}$ merupakan kelompok dari awal berdirinya sangat menutup diri terhadap hiruk-pikuk politik, gerakannya berfokus pada ibadah kepada Allah dan anggotanya dilarang mengikuti dunia perpolitikan. Sementara kelompok yang terakhir, Muslim Concil of Britain merupakan kelompok moderat yang mengakomodir terhadap sistem demokrasi.

Bertolak dari kedua pandagan yang menyatakan bahwa Shurā dan demokrasi berbeda, dan di sisi lain menyatakan sama dalam subtansi praktik, tentu saja kedua pandangan inilah yang menjadi pijakan awal sebagai kegelisahan akademik penulis untuk melakukan kajian mendalam. Bagaimana pandangan kiai dan santri di Madura dalam mempraktikkan Shurā dalam pusaran praktik demokrasi? Bagaimana meleburya praktik Shurā sebagai proses praktik demokrasi dalam

1 Lihat Bambang arif Rahman, Debating shura and democracy among British Muslim organizations, dalam Indonesian Journal of Islam and Muslim Societis, P.ISSN2089-14901/eISSN 240-825 X, Vol I, No.2 (2011), 229-252.

${ }^{2}$ Nasiri, Dkk, Kapila Selekta Dakwah, (Surabaya: Kopertai VI. 2016), hlm. 166-167. 
beberapa penentuan pilihan pimpinan organisasi dan politik kyai dan santri di Madura?

Teropong teori dalam kajian ini menggunakan "Melting Pot" sebuah teori sosial yang lazim digunakan dalam peleburan budaya sebagaimana pembentukan awal masyarakat Amerika yang terdiri dari berbagai unsur etnis emigrant yang datang dari berbagai belahan dunia yang berbeda-beda ras, suku, budaya dan agama kemudian melebur diri menjadi satu-kesatuan kelompok masyarakat baru yang dikenal dengan masyrakat Amerika. Teori ini penulis adopsi untuk melihat peleburan pemahaman dan praktik system demokrasi yang dilaksanakan di pondok pesantren sebagai konstektualisasi dari sistem shura dalam praktik demokrasi

\section{Shurā dan Demokrasi dalam Lintas Pemahaman.}

Shurā secara etimologi, barasal dari kata shāwara-yushāwiru, yang mempunyai arti "mengeluarkan madu dari sarang lebah" ${ }^{\text {, }}$ atau tepatnya bisa diartikan menjelaskan, menyatakan, atau mengajukan dan mengambil sesuatu. Bentuk lain yang berasal kata kerja shāwara adalah ashāra (memberi isyarat), tashāwara (saling bertukar pendapat atau berunding). Kata shurā itu sendiri diterjemahkan ke dalam bahasa Indonesia, yaitu musyawarah. Dengan demikian shurā atau musyawarah mempunyai pengertian saling menjelaskan, merunding dan tukar pendapat mengenai suatu hal.

Di dalam al Qur'an kata shurā disebutkan hanya dalam dua ayat, yaitu dalam surat al shurā, 42:38 dan Ali 'Imran ,3:159. Sementara Muhammad Iqbal dalam karyanya " Fiqh Siyasah Kontekstualisasi Doktrin Politik Islam" selain dua ayat tersebut memasukkan surat al Baqarah, 2:2334 sebagai bagian yang menjelaskan tentang shurā. Tetapi pendapat secara umum menyatakan bahwa shurā dalam al Qur'an hanya

\footnotetext{
${ }^{3}$ Lihat, Ibnu Manzur, Lisan al 'Arab, Jilid 4,1 434.

${ }^{4}$ Muhammad Iqbal, Fiqih Siyasah Kontektualisasi Doktrin Politik Islam, (Jakarta: Gaya Media Pratama,2007) 185
} 
disebutkan dalam dua surat, seperti yang dikemukakan oleh 'Akram Diya' al Umary, dalam kitabnya, 'Așru al Khilāfah al Rāshidah Muhāwalah linaqdi al Riwāyah al Tārihiyyat wafaqa manāhij al Muhaddithīna, merupakan sebuah prinsip hidup yang menjadi ciri dan sifat dari perilaku umat Islam. Hal itu tercermin dari perilaku Rasulullah yang selalu mengedepankan musyawarah dalam segala hal yang berkaitan dengan urusan dan persoalan dunia. Seperti yang telah diriwayatkan oleh Turmidi;

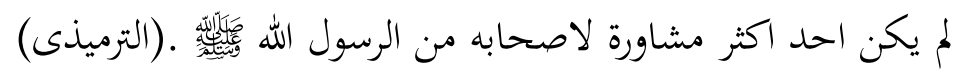

(Aku tidak pernah melihat orang yang banyak melakukan musyawarah melebihi para sahabat Rasulullah Saw).

'Akram Diya' al Umary, lebih tegas lagi menyatakan bahwa shurā (musyawarah) merupakan sebuah kewajiban yang harus dilakukan oleh umat Islam, karena pada dasarnya tidak ada ketentuan berdasarkan analisis sejarah yang menyatakan bahwa musyawarah adalah sunnah, baik yang telah dipraktikkan secara langsung oleh nabi maupun para sahabatnya. ${ }^{5}$ Akan tetapi 'Akram menjelaskan kewajiban tentang shurā tentunya tidak akan diterima oleh mayoritas masyarakat, karena memang tidak ada ketentuan secara pasti yang menyatakan tentang kewajiban shurā. Sehingga musyawarah merupakan sebuah tuntunan yang telah dipraktikkan oleh Rasulullah untuk senantiasa diikuti dan lakukan oleh umat Islam dalam berbagai aspek kehidupan. Contoh kongkrit bahwa Rasulullah selalu mengedepankan asas musyawarah seperti dalam memutuskan strategi pada perang Uhud. Bahwa pada saat itu Rasullah memenuhi keputusan musyawarah walaupun beliau sendiri berbeda pendapat dengan para sahabat mengenai strategi tersebut. ${ }^{6}$

\footnotetext{
5،Akram Diya' al Umary, Așru al Khilāfah al Rāshidah Muhāwalah linaqdi al Riwāyah al Tārihiyyat wafaqa manāhij al Muhaddithīna, (Riyad: Maktabah al 'Abikan, 1998) 97

${ }^{6}$ Ahmad Syafi'i Maarif, Islam dalam Bingkai Keindonesian dan Kemanusian Sebuah Refleksi Sejarah, (Bandung: Mizan, 2009), 159
} 
Muhammad Abid al Jabiri", menjelaskan bahwa shurā (musyawarah) di satu sisi bersifat ungkapan deskriptif, tetapi secara implisit bersifat imperatif, hal itu ditunjukkan dalam surat al Shurā. Di sisi lain shurā merupakan perintah eksplisit yang diarahkan langsung kepada diri nabi. Al Jabiri lebih lanjut menjelaskan bahwa posisi musyawarah dalam Islam merupakan kewajiban bagi penguasa dan hak bagi rakyat, bahkan paling utama adalah hak rakyat, karena para khalifah di masa Khulafā al Rāshidīn tidak akan diangkat kecuali dengan adanya proses musyawarah. Musyawarah dalam perkembangan pelaksanaannya bervariatif sesuai dengan kondisi dan konteks perkembangan masyarakat itu sendiri, karena musyawarah dilaksanakan oleh Rasulullah bersama para sahabatnya tidak berdasarkan pola dan bentuk tertentu.

Hal itu dapat dilihat dalam bentuk pengangkatan Khulafā al Rāshidīn dari Abu Bakar sampai Ali bin Abi Talib, masing-masing mempunyai pola dan bentuk yang berbeda. Fenomena perbedaan tersebut menghasilkan sebuah konsep tentang sistem pengangkatan pimpinan atau kepala negara dalam Islam. Al Mawardi memberikan batasan bahwa sahnya pengangkatan kepala negara dengan dua cara:8 Pertama, dengan cara dipilih melalui proses ahl al hāl wa al'aqd. Kedua, diangkat atau diberikan mandat dari pimpinan sebelumnya. Terangkatnya Abu Bakar sebagai khalifah yang pertama dikategorikan sebagai hasil proses musyawarah yang dilakukan oleh ahl al hāl wa al'aqd terbatas yang terdiri dari lima orang, kemudian diikuti oleh masyarakat pada saat itu. Proses bai'at khalifah tersebut dianggap sah walaupun sebagian dari masyarakat tersebut tidak mengikuti proses pemilihan tersebut. Berbeda dengan Umar bin Khattab, diangkat berdasarkan penunjukkan atau mandat dari khalifah Abu Bakar. Utsman bin Affan diangkat melalui proses pemilihan

\footnotetext{
${ }^{7}$ Muhammad Abid al Jabiri,Syura Tradisi Partikularitas Universalitas,(Terjemah: Mujiburrahman), (Yogyakarta: LkiS, 2003),164

${ }^{8}$ Lihat, Abi al Hasan bin Muhammad bin Habib al Basari al Baghdadi al Mawardi, al Ahkām al Sultāniyyah..., 7
} 
yang dipersiapkan oleh khalifah Umar dengan cara membentuk tim formatur yang terdiri dari enam orang. Tim formatur tersebut sekaligus berhak menjadi kandidat dalam pemilihan, sehingga satu berpeluang sebagai yang terpilih, dan lima orang lainnya yang menentukan dan memilihnya. Realitas ini kemudian menjadikan batasan minimal dalam proses pemilihan ahl al hāl wa al 'aqd' bagi kalangan mayoritas ulama Basrah. Walaupun batasan minimal ini dibantah oleh mayoritas ulama kalangan Kufah yang menyatakan bahwa batasan minimal dalam pemilihan kepala negara bisa dilakukan oleh tiga orang. Satu sebagai kandidat yang berpeluang sebagai kepala negara dua orang lain memilih dan menyetujuinya. Proses ini sama halnya dengan proses akad pernikahan, satu sebagai wali, dua orang lainnya sebagai saksi.

Konsep shurā (musyawarah) dalam perkembangan berikutnya dihadapkan dengan model demokrasi sebagai sistem pemilihan dalam pemerintahan yang dianut dalam beberapa negara tidak terkecuali negara yang terdiri dari mayoritas umat Islam. Kenyataan ini kemudian memunculkan beberapa pandangan. Pandangan yang pertama, menyatakan bahwa sistem shurā dan demokrasi berbeda satu sama lain. Pandangan lainnya menyatakan bahwa shurā dan demokrasi merupakan sistem yang secara subtansial mempunyai kesamaan. Dalam pandangan penulis, bahwa musyawarah dan demokrasi merupakan sistem yang berbeda, tetapi mempunyai titik temu yang sama. Musyawarah mempunyai dasar normatif yang bersumber dari al Qur'an yaitu dalam surat al shurā, 42:3810 dan Ali ‘Imran ,3:15911, pada dasarnya menekankan

${ }^{9}$ Abi al Hasan, ibid, 7

${ }^{10}$ al Imām al Jalīl 'Imād al dīn 'Ab̄̄ al Fidā' Ismaīl ibn Umar ibn Kathīr al Qurshiyyi al Dimashqiyyi, Tafsīr al Qur'an al 'Az̄ìm al Ma'rūf, Cetakan ke VIII, Jilid 4.( Dār al Salām li al Nashri wa al Tauz̄̄', 2004), 2526. Ibn Kathīr menjelaskan bahwa mereka (para sahabat) tidak melaksanakan suatu perkara kecuali dengan putusan musyawarah, sehingga mereka bisa saling dukung-mendukung melalui pendapat mereka. Seperti putusan musyawarah mengenai peperangan dan urusan lain yang tersurat dalam firman Allah; "Dan bermusyawarahlah dengan mereka dalam urusan itu". Maka dari itu Rasulullah bersama para sahabatnya dalam menentukan peperangan dan urusan sejenisnya agar hati mereka menjadi baik. Begitu juga dalam pergantian kepemimpinan khalifah Umar bin Khattab, setelah beliau ditusuk oleh seseorang, maka beliau membetuk tim 
adanya keterlibatan masyarakat dalam memutuskan suatu dengan cara musyawarah dan mufakat (konsensus). Walaupun musyawarah dan mufakat dilakukan dengan cara keterwakilan ahl al häl wa al aqd, baru kemudian diikuti oleh masyarakat secara umum. Demokrasi itu sendiri pada hakikatnya merupakan kreasi manusia yang disepakati sebagai konsep dan pemikiran dalam memandang hak dan kewajiban manusia, yang menekankan adanya otoritas sepenuhnya berada ditangan rakyat sebagai sebuah keputusan dan sumber hukum.

\section{Peleburan Kontekstualisasi Shurā dalam Praktik Demokrasi}

Peleburan sistem shurā dan demokrasi karena adanya kesamaan semangat untuk menegakkan keadilan dan persamaan hak. Konsep demokrasi pada dasarnya memberika perhatian besar terhadap masalahmasalah yang berkaitan dengan hak asasi manusia, kebebasan, dan keadilan sosial. Sebagai sistem yang mengatur kemaslahatan bermasyarakat dan bernegara, demokrasi mempunyai titik temu dengan konsep shurā yang di dalamnya menjunjung tinggi keadilan, persamaan hak dan prinsip-prinsip kebebasan masyarakat.

Muhammad Abid al-Jabiri, yang menyatakan peleburan sistem shurā dan demokrasi harus melalui aktualisasi konsep shurā dalam sistem demokrasi. Hal itu didasari bahwa bangunan politik adalah etika Islam dalam pemerintahan yang menjalankan tiga prinsip dasar sebagaimana yang telah dilakukan Nabi, yaitu adanya musyawarah, adanya tanggung jawab dan pembagiannya dalam satu struktur masyarakat, dan yang terakhir pernyataan Nabi mengenai, "Kamu lebih mengetahui urusan-

formatur yang terdiri dari enam orang untuk melakukan musyawarah. Tim formatur tersebut terdiri dari: Utsman bin Affan, Talhah, Zubair, Sa'ad dan Abdurrahman bin Auf, kemudian mereka sepakat Utsman bin Affan sebagai khalifah pengganti Umar bin Khattab.

${ }^{11}$ Ibid, Jilid 1, 575 "Dan bermusyawarahlah dengan mereka dalam urusan itu”. Berkaitan dengan ayat ini Rasulullah senantiasa mengajak para sahabatnya untuk melakukan musyawarah mengenai persoalan yang terjadi, agar hati mereka senang dan lebih bersemangat dalam beraktifitas. Hal itu dibuktikan dengan sabda Nabi; قال لابى بكر وعمر : لواجتمعنا فى مشورة ما خالفتكما Bersabda Nabi kepada Abu Bakar dan Umar; Jika kami berkumpul untuk bermusyawarah, saya tidak pernah berbeda pendapat dengan kalian berdua (Abu Bakar al Șiddiq dan Umar bin Khattab). Hadith ini diriwayatkan oleh Imam Ahmad, diceritakan Waqi', dan diceritakan oleh Abd al Hamid bin Shahir bin Haushab dari Abd al Rahman bin Ghanam. 
urusan duniamu12. Tiga dasar inilah dalam pandangan al-Jabiri yang menjadi pijakan etika Islam dalam urusan pemerintahan dan politik. Implementasi musyawarah tersebut, kata al-Jabiri harus dilakukan melalui proses pemilu yang bebas dan demokratis, adanya pembatasan kepala negara, disamping juga perlunya eksekutif bertanggung jawab terhadap parlemen baik dalam sistem kerajaan maupun republik. Serta adanya pembatasan wewenang kepala negara, pemerintah, dan parlemen, sehingga parlemen menjadi satu-satunya sumber kekuasaan.

Al-Jabiri lebih lanjut menegaskan bahwa prinsip model musyawarah ini yang harus dilakasanakan pada masa sekarang. Dengan demikian al Jabiri menolak pendapat al Mawardi dan tokoh-tokoh tradisionalis lainnya sebagai rujukan dalam pembentukan kembali pemikiran politik Islam, sebab pendapat mereka dibentuk dan diterpa oleh kondisi zaman mereka ${ }^{13}$. Kondisi sekarang menuntut Islam mampu membingkai secara etik dalam berbagai aspek persoalan kehidupan manusia termasuk di dalamnya ekonomi, sosial budaya dan politik pemerintahan. Inilah yang disebut Islam sebagai cerminan dari sālih likulli makān wa zamān.

Lebih tegas lagi titik temu yang ditawarkan Abdillah, bahwa perlu adanya sinergisitas antara Islam dan demokrasi. Tawaran ini yang dikenal dengan konsepnya demokrasi religious. Dalam pandangannya demokrasi sebagai sistem nilai tidak cukup dibingkai dalam frame paham sekularisme tapi juga dalam bingkai yang relegious, yang menghormati nilai-nilai agama dan budaya lokal ${ }^{14}$. Lebih lanjut ia menyatakan demokrasi yang religious adalah memberikan "kebebasan dan toleransi, sebagai nilai-nilai dasar demokrasi, disamping persamaan dan keadilan. Oleh sebab itu karena Indonesia bukan negara agama, maka hubungan

\footnotetext{
${ }^{12}$ Lihat, Muhammad Abid al-Jabiri, Agama, Negara dan Penerapan Syariah, (Terj:Mujiburrahman) (Yogyakarta: Fajar Pustaka Baru, 2001) 85

${ }^{13}$ Ibid, 88

${ }^{14}$ Masykuri Abdillah, Menuju Demokrasi Yang Religius, dalam http://www.nu.or.id/page. php?lang=id\&news_view_id=1253 (20 Februari 2004)
} 
antara agama dan politik tidak bisa bersifat formal-legal, tetapi yang lebih sesuai adalah hubungan yang bersifat subtantifistik ${ }^{15}$. Ia melihat kesinergisan sistem demokrasi khususnya di Indonesia karena dua hal;16 Pertama, nilai-nilai demokrasi sesuai dengan nilai-nilai Islam tentang masyarakat. Kedua, cara yang tepat untuk mengartikulasikan aspirasi dan kepentingan-kepentingan Islam. Karena umat Islam di Indonesia adalah mayoritas, sementara sistem yang demokratis pada dasarnya adalah sistem kekuasaan mayoritas. Mengacu pada konsep Masykuri Abdillah tersebut, maka keinginan menjalankan nilai-nilai Islam melalui bangunan sistem kenegaraan yang dianut dalam hal ini demokrasi. Karena demokrasi yang diterapkan di Indonesia telah mengakomodir nilai-nilai dan tujuan agama.

\section{Aktualisasi shurā dalam Praktik Demokrasi di Pondok Pesantren.}

Pondok pesantren sebagai komunitas yang terdiri dari Kiai, Ustadz dan santri, menempatkan Kiai sebagai posisi sentral dalam memberikan kebijakan dan keputusan dalam berbagai hal. Seiring dengan pembaharuan pendidikan yang dilakukan pondok pesantren dengan berpijak kepada al muhafadzah ala qadim al shaleh, wa al akhdu 'ala jadid al ashdalalah, dengan mengadopsi pendidikan formal baik madrasah, sekolah dan perguruan tinggi memberikan dampak perubahan terhadap pengelolaan dan sistem kepemimpinan yang diterapkannya. Pergeseran dan dinamisasi sistem yang awalnya pemilihan ketua OSIS di madrasah dan sekolah di lingkungan pondok pesantren melalui proses musyawarah terbatas dalam menentukan beberapa kandidat yang dipilih oleh Ustadz. Selanjutnya para kandidat diajukan kepada Kiai melalui munajat dan ketentuan (istikhara). Pola ini merupakan kecenderungan gaya kepemimpinan religio-patenalistik, Kiai diakui sebagai orang yang

\footnotetext{
${ }^{15}$ Ibid

${ }^{16}$ Masykuri Abdillah, Demokrasi di Persimpangan Makna; Respon Intelektual Muslim Indonesia terhadap Konsep Demokrasi (1966-1993), (Yogyakarta: Tiara Wacana, 1999) 76.
} 
mempunyai kekasyfan ${ }^{17}$ keilmuan sehingga segala keputusan yang dilakukukannya merupakan kebenaran petunjuk Tuhan. Sementara ustadz dan santri menerima hasil keputusan sebagai sebuah prinsip kepatuhan (sami'na wa atha'na) ciri khas tradisi pesantren. Saat ini proses pemilihan OSIS dan pemilihan organisasi lainnya merupakan wilayah wewenang yang dilakukan oleh siswa sendiri melalui proses pemilihan sistem demokrasi.

Pemilihan ketua OSIS (Organisasi Intra Sekolah) di Madrasah Aliyah Pondok Pesantren Darul Ulum Banyuanyar merupakan merupakan peleburan kontektualisasi shurā dalam sistem demokrasi, seperti yang digambarkan Syamsul Satrana ${ }^{18}$, bahwa calon dari perwakilan masing-masing program jurusan; IPA, IPS dan Bahasa merupakan satu paket yang terdiri dari calon ketua dan wakil ketua OSIS sekaligus. Calon dari perwakilan tersebut sebelum dipilih langsung oleh seluruh siswa Madrasah Aliyah, mengikuti tahapan fit and proper test yang dilakukan oleh pembina OSIS dan ustadz yang ditunjuk. Tahapan ini hampir sama dengan ahl al hal wa al aqd, hanya saja perbedaan mendasar dari tahapan fit and proper test ini dilakukan oleh tim panelis khusus untuk mengukur kompetensi kepemimpinan masing-masing kandidat yang diusung. Sementara ahl al hal wa al aqd pada masa Khulafā al Rāshidīn dalam proses pemilihan Khalifah Utsman bin Affan, terdiri 6 tim yaitu; Utsman bin Affan, Alin bin Abi Thalib, Abdurrahman bin 'Auf, Saad bin Abi Waqas, Thalhah bin Ubaidillah, Zubair bin al Awam, dan Abdullah bin Umar putra dari Khalifah Umar bin Khattab ${ }^{19}$, selain berfungsi untuk mengukur kapasitan dan kualitas calon pemipimpin melalui dialoq dan jajak pendapat, mereka otomatis sebagai konstestan dari pemilihan tersebut.

17 Zainuddin Syarif, Dinamisasi Manajemen Pendidikan Pesantren: Dari Tradisional Hingga Modern, (Edisi Revisi), (Pamekasan: Mega Media, 2017), 124

${ }^{18}$ Wakil Kepala bidang kesiswaan, 12 Mei, 2019

${ }^{19}$ Lihat, Akram Diya' al Umary, Așru al Khilāfah..56-57. 
Pemilihan OSIS, merupakan kontestasi politik santri, sebagai wadah aspirasi politik santri yang memenuhi aspek "al musyawa wa al muadalah bagian yang tidak terpisahkan dari dasar-dasar pemerintahan dalam Islam yang di dalamnya juga disebutkan pertalian dan persaudaran Islam, dan gerakan sosial ${ }^{20}$, tidak hanya sebagai wadah untuk memilih ketua dan wakil ketua OSIS, tetapi merupakan proses pembelajaran bagi santri sebagai bagian dari warga Negara yang mempunyai pemahaman terhadap demokrasi yang membutuhkan pola hubungan yang sehat ${ }^{21}$, hormat, dan saling menghargai antara pemimpin dan yang dipimpin.

Pengenalan terhadap konsep kepemimpinan dalam pondok pesantren tidak melalui kajian secara khusus, sehingga sebagian dari mereka merasa asing dengan istilah-istilah dalam konsep kepempimpinan tersebut. Hal ini ditegaskan oleh Ustadz Fauzi ${ }^{22}$ selaku guru mata pelajaran fiqih, bahwa rata-rata siswa asing terhadap konsep dan sistem shurā, termasuk juga tentang sistem perpolitikan yang berkembang saat ini. Kedangkalan pengetahuan santri terhadap sistem shurā dan perpolitikan, disebabkan karena transmisi keilmuan pada bidang fiqih lebih dominan kepada persoalan fiqih ubudiah dan muamalah, sementara persoalan fiqih jinayah dan siyasah cenderung terabaikan. Sekalipun dalam kitab fiqih terdapat pembahasan tentang jinayah dan siyasah ditelaah tidak secara mendalam dan serius hanya sekedar menjadi ulasan teks semata.

Secara subtabsi kiai Abdul Mukti Tabrani23 mengakui bahwa demokrasi merupakan peleburan dari shurā yang tidak terpisahkan. walaupun pada dasarnya antara shurā dan demokrasi masing-masing berbeda baik pada tataran teoritis maupun secara praktis. Shurā dalam

\footnotetext{
${ }^{20}$ Muhammad Syaltut, Al Islam Aqidah wa Syariah, (Mesir: Dar al Qalam, 1966) Cet ke-3, 441.

${ }^{21}$ Lihat, A.A. Said Gatara, Moh.Dzulkiah Said, Sosiologi Politik Konsep dan Dinamika Perkembangan Kajian, (Bandung: Pustaka Setia, 2007, 199.

${ }^{22}$ Wawancara, 28 Juni, 2019.

${ }^{23}$ Tenaga pengajar senior di SMA Isbatiah Pondok pesantren Banyuanyar, wawancara, 08 Maret, 2019.
} 
praktiknya merupakan proses pilihan melalui perwakalin yang ditentukan yaitu ahl al hal wa al aqd. Sementara proses demokrasi merupakan suara rakyat melalui proses pmilihan langsung dari rakyat tanpa adanya perantara perwakilan. Proses pemilihan demokrasi ini dikenal dengan one man one vote. Kontekstualisasi wa amruhum shura bainahum dalam praktiknya terjadi dinamika perbedaan dalam penerapannya, seperti yang digambarkan dalam praktik khulafa al Rasyidiin. Naiknya Abu Bakar Al Siddik sebagai khalifah pertama, melalui proses al ta'yin (penunjukan) oleh Umar bin Khattab, yang dilanjutkan proses bai'ah ${ }^{24}$ kepada mayarakat secara luas. Pemilihan khalifah Utsman bin Affan melului proses pembentukan formatur atau perwakilan (ahl al hal wa al aqd) untuk memilih para kontestan yang yang salah satunya adalah putra dari khalifah Umar bin Khattab. Umar sebagai khalifah pada saat itu mewanti wanti keikutsertaan putranya hanya sebagai konstestan saja tidak untuk dipilih.

Menurut kiai Abdul Mukti Thabrani ada dua faktor yang mendasari terjadinya peleburan kontekstualisasi shurā dalam praktik demokrasi dalam pesantren yaitu; Pertama secara normatif mereka memahami teks hadits al mu'minuna 'ala syrutihim, sebagai bentuk kepatuhan dari warga negara untuk mengikuti apa yang menjadi pilihan dan kesepakatan sistem politik yang dianut dalam suatu negara. Karena Indonesia memilih demokrasi sebagai sistem negara maka, sebagai warga negara yang baik wajib mengikutinya. Kedua, atiullah wa atiu al rasul wa ulil amri minkum"25, merupakan bentuk pemahaman yang mengikat,

\footnotetext{
${ }^{24}$ Baiáh merupakan proses sumpah setia masyarakat kepada khalifah yang dipilih selagi khalifah masih bersikukuh dan tidak melanggar terhadap hukum syariah. Tentu saja proses baiáh berbeda dengan sumpah janji jabatan Presiden yang terpilh malalui proses demokrasi. Pesiden bersumpah dan berjanji sebagai amanah rakyat untuk melaksanakan sesuai dengan undang-undang yang berlaku.

${ }^{25}$ Menurut Mohammad Imarah, Ulil Amri Minkum, merupakan kelompok atau bagian dari ahl al hal wa al aqd yang terdiri pemerintah baik eksekutif maupun legislatif termasuk di dalamnya kekuasan yudikatif, dimana kekuasaan dan kebijakannya merupakan kebutuhan dan kemaslahatan masyarakat secara umum, Islam al Siyasah al Raddu 'Ala Syibhati al 'Ilmaniyyin, (Mesir: Dar al Tauzii' wa al Nushur al Islamiyah, 2007) 33.
} 
bahwa bentuk kepatuhan kepada Allah dan rasulnya adalah mengikuti dan mematuhi pemerintah dan ketetapannya. Imarah menegaskan bahwa kepatuhan terhadah pemerintah yang dimaksud adalah peraturan atau regulasinya tidak mengarahkan kepada kemaksiatan dan pelanggaran kepada syariat.

\section{Kesimpulan}

Peleburan shurā dan demokrasi di pondok pesantren Darul Ulum Banyuanyar dapat ditemukan dalam kontestasi politik santri pada pilihan OSIS karena mereka (santri) sebagai representasi, memahami praktik demokrasi sebagai satu-satunya sistem yang cocok baik dalam aspek agama dan sosial politik. Hal itu disebabkan karena mereka lebih familiar atau mengenal sistem demokrasi daripada shurā. Bagi kalangan kiai dan Ustadz peleburan shurā dan demokrasi karena mereka merasakan secara subtansi baik shurā dan demokrasi berorientasi pada tegaknyan al muadalah wal al musyawa (keadilan dan persamaan hak), sehingga mereka mempunyanyai pemahaman bahwa praktik demokrasi sesungguhnya merupakan kontekstualisasi shurā. 


\section{Daftar Pustaka}

Bambang arif Rahman, Debating shura and democracy among British Muslim organizations, dalam Indonesian Journal of Islam and Muslim Societis, P.ISSN2089-14901/e-ISSN 240-825 X, Vol I, No.2 (2011) 166-167.

Nasiri, Dkk, Kapila Selekta Dakwah, (Surabaya: Kopertai VI. 2016), hlm.

Ibnu Manzur, Lisan al 'Arab, Jilid 4,1 434.

Muhammad Iqbal, Fiqih Siyasah Kontektualisasi Doktrin Politik Islam, (Jakarta: Gaya Media Pratama,2007)

'Akram Diya' al Umary, Assu al Khilāfah al Rāshidah Muhāwalah linaqdi al Riwāyah al Tārihiyyat wafaqa manāhij al Muhaddithīna, (Riyad: Maktabah al 'Abikan, 1998)

Ahmad Syafi'i Maarif, Islam dalam Bingkai Keindonesian dan Kemanusian Sebuah Refleksi Sejarah, (Bandung: Mizan, 2009)

Muhammad Abid al Jabiri,Syura Tradisi Partikularitas Universalitas,(Terjemah: Mujiburrahman), (Yogyakarta: LkiS, 2003)

Abi al Hasan bin Muhammad bin Habib al Basari al Baghdadi al Mawardi, al Ahkām al Sultāniyyah...

al Imām al Jalīl 'Imād al dīn 'Abī al Fidā' Ismaīl ibn Umar ibn Kathīr al Qurshiyyi al Dimashqiyyi, Tafsìr al Qur'an al 'Ażim al Ma'rüf, Cetakan ke VIII, Jilid 4.( Dār al Salām li al Nashri wa al Tauzī', 2004)

Muhammad Abid al-Jabiri, Agama, Negara dan Penerapan Syariah, (Terj:Mujiburrahman) (Yogyakarta: Fajar Pustaka Baru, 2001)

Masykuri Abdillah, Menuju Demokrasi Yang Religius, dalam http://www.nu.or.id/page. php?lang=id\&news_view_id=1253 (20 Februari 2004)

Masykuri Abdillah, Demokrasi di Persimpangan Makna; Respon Intelektual Muslim Indonesia terhadap Konsep Demokrasi (1966-1993), (Yogyakarta: Tiara Wacana, 1999).

Zainuddin Syarif, Dinamisasi Manajemen Pendidikan Pesantren: Dari Tradisional Hingga Modern, (Edisi Revisi), (Pamekasan: Mega Media, 2017).

Muhammad Syaltut, Al Islam Aqidah wa Syariah, (Mesir: Dar al Qalam, 1966) Cet ke-3, 441.

A.A. Said Gatara, Moh.Dzulkiah Said, Sosiologi Politik Konsep dan Dinamika Perkembangan Kajian, (Bandung: Pustaka Setia, 2007.

Mohammad Imarah, Islam al Siyasah al Raddu 'Ala Syibhati al 'Ilmaniyyin, (Mesir: Dar al Tauzii' wa al Nushur al Islamiyah, 2007). 